\title{
Patterns and Interpretation of Tafsir Science
}

\author{
Mochamad Imamudin \\ Universitas Islam Negeri Malang \\ mochimamudin@gmail.com
}

\begin{abstract}
The Qur'an is the revelation of God with the absolute truth that is the source of Islamic teachings. The Qur'an is a holy book for Muslims who give clues to the right path. It serves to provide welfare and happiness for people, both personally and in groups. He was also a place of grievances and outpouring of hearts for those who read it. The Qur'an is like an ocean that never dries its water, its waves never subsides, the riches and treasures that it contains never run out, can be crossed and interrown in various ways, and provide tremendous benefits and impacts for life Human. In his position as Scripture and miracles for the Muslims, the Qur'an is a source of security, motivation, and inspiration, the source of all legal resources that are never dry for the one who imfew it. It contains historical documents that record socio-economic, religious, ideological, political, and cultural conditions of human civilization until the VII-century AD. If that is the case, then the understanding of the verses of the Qur'an through interpretation, having a very large role for the development of the people, guarantees the key term to open the warehouse of the Simsimpani that is buried in the Qur'an. As a living guideline for all ages, and in many aspects of human life, the Qur'an is an open ended scripture to understand, interpret and be offered in the perspective of the interpretation method and the perspective of the dimensions Human life. From here there came the sciences to study the Qur'an from various aspects, including the science of interpretation. This paper will discuss about the science of Tafsir covering its history and development, as well as patterns and methods in interpretation.
\end{abstract}

Keyword : Patterns, interpretation, Tafsir Science

\section{INTRODUCTION}

Experts give interpretation of both etymologically and terminology on the term of interpretation. Etymologically the word interpretation means al-Ibanah wa kasyfu al-Mughattha (explain and unveil the enclosed). In the Al-'arab oral dictionary, tafseer means to reveal the vague meaning of the word. It is based on the word of God Sûrah al-Furqân: 33

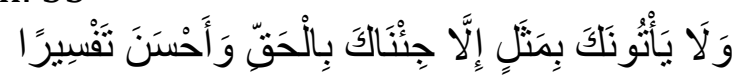

"Not the disbelievers come to you (bring) something odd, but we bring to you the right and the best explanation" (Manna, 1973)

Whereas the terminology of authors will reveal the opinion of experts. Al-Zarqoni explains the interpretation is the science to understand the Qur'an that is revealed to the Prophet Muhammad by explaining Makna-maknanya and issuing the law and Hikmah-hikmahnya. (Zarqoni, 1995) 
According to Abû Hayyân as was quoted by Manna al-Qaththân, it defines the interpretation as a science which discusses how the pronunciation of the pronunciation of the Qur'an, Petunjuk-petunjuknya, its laws both when standing alone or composed, and the meaning possible him when composed and anything else that complemented him.

The science of Tafseer is a part of the science of Shari'ah, the most exalted of its position, because its discussion is related to Kalamullah which is the source of all wisdom, as well as instruction and differentiator from the Haq and Bathil. The science of Tafsir has been known since the time of Rasulullah and develops until today's modern times. The need for the interpretation of the increasingly urgent due to religious perfection can be achieved when in accordance with the Shari'ah, while the conformity with the sharia depends on the knowledge of the Qur'an. (Suyuti, 1972)

Thus the review of the definition of interpretation. It is important to know, because in the development of interpretation will appear diversity and change at a certain time. Modern scholars, of course, will see "Tafseer" with previous scholars. Below will the author will expose his reviews on the development of interpretations and interpretations from classical to modern times.

\section{DISCUSSION}

\section{History and development of Tafsir science}

1. Tafseer in Classical period

To facilitate the discussion on the development of interpretation in classical times, the authors will map in three discussions, namely (1). Tafseer during the Prophet and companions. (2). Tafseer at the time of Tabi'in and (3). Tafseer at the time of codification (bookkeeping).

a. Tafseer during the prophet and companions

The interpretation activity has begun since the Prophet Muhammad was still alive. The Prophet became a central figure in the interpretation of the Qur'an. For friends, to know the meaning of the Qur'an is not too difficult. Because they directly faced with the Prophet as a presenter of Revelation, or to another friend who understands better. If there is meaning that is less understandable, they immediately ask the prophet. So that a feature of interpretation that develops among friends is the provertion of the prophet. This emphasises the word of God Sûrah al-Nahl: 44 that the Prophet was sent to explain the content of the Qur'anic verses.

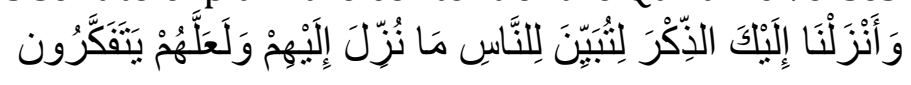

"And we have sent down unto thee the Qur'an, that ye shall explain to mankind what has been handed down to them, and that they may think". 
There are very few companions who use the interpretation of ra'yî in interpreting the Qur'an. Among friends who firmly reject the use of reason in the interpretation are Abû Bakar and Umar ibn Khattâb. Abû Bakar once said:

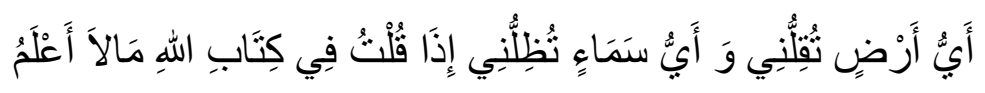

"Which Earth holds me and what heaven overshadowed me, when I say of the Book of God something I do not know"

He said so when people asked about the meaning of Abbân. The statement also shows that Abû Bakar did not justify anything about the book of God if he used Ijtihad, Bil ra'yî. But there are also some friends who interpret the Qur'an with ijtihad bil ra'yî besides the history, namely Ibn Mas'ûd and Ibn Abbâs (As-siddiq, 1900).

Broadly, the companions adhere to three things in interpreting the Qur'an, which is the Qur'an itself, the Prophet Muhammad as the explanatory (Mubayyin) of the Qur'an, and Ijtihad.

In this era the science of Tafseer was not recorded at all, because the bookkeeping began in the 2 nd century $\mathrm{H}$. Tafseer In this era is one branch of hadith, the condition has not been arranged systematically, and still narrated randomly for verses that Different (Qahtan, 1921).

b. Tafsir at the time of Tabi'in

After generations of companions passed, Exegetes appeared afterward, the Tabi'in. Tafseer at the time of Tabi'in has undergone fundamental differences from before. If the companions are based on a specific person (the Prophet and Sabahat himself), then the interpretation that develops in the time of Tabi'in began to rely heavily on the news Israiliyyât and Nasrâniyyât. In addition, the interpretation of Tabi'in also contaminated with sectarian elements by area or sect. It was because of the tabi'in that once learned from friends spread to various regions.

There are three major streams at the time of Tabi'in. First, the traditions of Makkah, Sa'îd ibn Jubaîr (d. 712/713 A.D.), Ikrimah (d. 723 M), and Mujâhid ibn Jabr (d. 722). They studied at the Ibn Abbâs. Second, the flow of the Medina, Muhammad ibn Ka'âb (d. 735 A.D.), Zaîd ibn Aslâm al-Qurazhî (d. $735 \mathrm{M}$ ) and Abû Aliyah (d. $708 \mathrm{M}$ ). They studied at Ubay ibn Ka'âb. Thirdly, the Iraqi sect, Alqamah ibn Qaîs (d. 720 A.D.), Amir al-Sya'bî (d. 723 M), Hasan al-Bashrî (d. 738 ad) and Qatâdah ibn Daimah al-Sadûsi (d. 735 M). They studied at Abdullah ibn Mas'ûd (Mustaqim, 2011).

According to Ibn Taymiyah, that the Sepandai-pandainya Ulama Tabi'in in the affairs of interpretation are the companions of Ibn Abbâs and Ibn Mas'ûd and the Medina scholars such as Zaîd ibn Aslâm and Imam Malîk Ibn Anas. Furthermore, Ibn Taymiyah saw that Mujâhid was a great 
exegetes. Until al-Shaafa'i and Imam Bukhari hold on to him(Taimiyah, 1971). But there is also a view that rejects the interpretation of Mujâhid. This is because Mujâhid asked a lot of members of the book (Hasbi, 2002). In addition to the many cited members of the book, Mujahid is also known as a exegetes that gives a wide portion of the freedom of mind in interpreting the Qur'an (Husain, 2005).

The scholars differed concerning the interpretation derived from Tabi'in if the interpretation is not narrated by any prophet or friend. They doubt whether the opinion of the Tabi'in can be disvisited or not. Those who reject the interpretation of Tabi'in argue that the Tabi'in does not witness the events and conditions when the Qur'anic verses are derived. While the people who support the interpretation of Tabi'in can be held as a position stating, that the Tabi'in narrated from the companions (alqahtan, 1921).

c. Tafseer in the period of codification

After generations of Tabi'in, Tafseer began to be codified. The period of the Tafseer was initiated at the end of the Umayyad administration and the beginning of the Abbasid (c. 2 century). At the beginning of the Abbasid, the scholars began the writing of Tafseer by collecting hadist of Tafseer narrated from the Tabi'in and companions. They compiled the interpretation by mentioning the text and quoting hadith related to the verse from the friend and Tabi'in. So the interpretation is still part of the Hadith book. Among the scholars who gathered the hadith to get the interpretation are: Sufyân ibn Uyainah (198 H), Wakî ' ibn Jarrah (196 H), Shu'bah ibn Hajjâj (160 H), Abdul Rozaq bin Hamam (211 H).

After the scholars, the interpretation began to be separated from the books of hadith. Until the interpretation became a science of itself. Tafseer was written systematically according to the Tartib Mushaf. Among the scholars of Tafseer at this time was Ibn Maajah (d. 273 H), Ibn Jarîr al-Thabâri (d. 310 H), Ibn Abî Hatîm (d. 327 H), Abu Shaikh Ibn Hibbân (d. 369 H), AlHakîm (d. 405 H) and Abû Bakar Ibn Mardawaih (d. 410 H).

While al-Dhahabî divides several stages of interpretation at the time of codification based on characteristic and characteristic. First, the writing is in conjunction with the Hadith. At the time of hadith was recorded, the interpretation became part of the chapter itself. Second, the writing of interpretation separated from the book of Hadith. But the writing of interpretation is based on the discussion that is held on the prophet, friend, Tabi'in and Tabi'ut Tabi'in (source of interpretation of Bil Ma'tsur). Thirdly, this stage of writing of interpretation still lists the histories. But there is a very significant difference that the histories do not come with the Isnaad. At this stage, al-Dzahabî signals the forgery of the interpretation and 
permualan the beginning of the stories Israiliyyât in Tafseer. Fourth, the source of interpretation at this time is no longer limited to classical clerical researchers, but also based on Ijtihad, Bil Ra'yi.

2. Tafseer in the Middle Ages

The development of medieval interpretation began in the 9th century AD until the 19th century AD in this century, the development of science was at the Golden Age. The development of interpretation was not separated from the development of science at the time the interpretation was written. Tafsir is then loaded with the disciplines of the knowledge and the tendency of Toelogis, for the Mufassir. The Qur'an is often used to legitimize the interests of certain schools.

Among the books of "Akbar" that emerged in the golden era of Islam/mediaeval are: Jamî ' al-Bayân an ta'wîl al-Qur'ân by Ibn Jarîr alThabarî (d. 923 M/310 H); Al-Kasysyâf an Haqâ'iq al-Qur'ân by Abû al-Qasîm Mahmûd ibn Umar al-Zamakhsyari (d. 1144 M/528 H); Mafâtih al-Ghaib by Fakhruddîn ar-Râzi (d. 1209 M/605 H) and Tafsîr Jalâlaîn by Jalâluddîn Mahallî (d. 1459 M) and Jalâluddîn al-Suyûti (d. 1505 M).

In the next development came the interpretation of Ibn Arabi $(638 \mathrm{H})$ which is also often received criticism. This was because Ibn Arabi interpreted the Qur'an to support his thigh, of existed. The birth of Imâduddîn Ismail ibn Umar ibn Katsîr at 700 H/1300 AD, also contributed to the interpretation of the century. The Tafsîr al-Qur'ân al-Karîm consisting of ten volumes became a well-known work in addition to the other books he wrote. In the century it appears also the interpretation of Jamî ' al-Ahkâm al-Qur'ân by Abdullah alQurtubî (671 H). Many scholars have considered that he was a Maliki scholar, and the Tafseer was fiqh, but al-Qurtubî did not restrict the review of the legal passages. More than that, he interpreted the Qur'an as a whole. It is commonly preceded by explaining the Asbâb Nuzûl, Qira'at, i'rab, and clarifying pronunciation of the gharib.

In addition to the name of the exegetes above, appears also Alî ibn Muhammad al-Baghdadî (678-741 H) with the works of Tafsîr Lubâb al-ta'wîl fî ma'âni tanzîl, or often referred to by the Tafseer al-Khâzin. The sources of interpretation in the Tafseer are Bil ma'tsûr. Al-Khâzin pays considerable attention to the stories of Isrâiliyyât. So there are some of his interpretations that are considered distorted by Husein al-Dzahabî.

In $754 \mathrm{H}$ appeared to be Tafseer Bahrul Muhît by Ibn Abû Hayyân al-Andalusî. In his book of Tafseer consisting of eight volumes, he paid much attention to the problems I'rab and NAHWU. Because of the considerable attention in the issue of NAHWU, many people call this book more suitable to be called NAHWU, not interpretation. He quoted the opinion of Zamakhsyari in the 
science of NAHWU. But Abû Hayyan often does not agree with Zamakhsyari, more about his understanding of his.

In addition to the names above, there are many more mufastators of tafseer that appear in the Middle Ages. Each has a character that is typical of the author of the interpretation. As the author expressed above, that in the Middle Ages happens to acculturation of culture because of the spread of Islam to the world, so this also creates a difference of interpretation based on the difference between the sect and the place.

\section{Tafseer in Modern era}

Cultural acculturation in the Middle Ages is quite felt to influence the Qur'anic interpretation of the century. Similarly, in modern times, the presence of colonialism and the influence of Western thought in the century 18-19 M strongly affects the mufastators of this era. The development of science is allegedly strong to be the main factor of the interpreter in giving response. The rational thinking that became the identity of the modern era then became the commentators ' initial footing. They generally believe that Muslims do not understand the spirit of the Qur'an, so they fail to capture the rational spirit of the Qur'an.

On the basis of rationalistic thought, most of modern Muslim thinkers interpret the Qur'an with rational reasoning, with the interpretation of the Qur'an with Qur'anic interpretations, or return to the Qur'an. Then they oppose the legend, primitive ideas, fantasy, magical and Myth.

According to Baljon in his book titled Modern Muslim Koran Interpretation, saying that the so-called modern tafsir is the effort that the mufastators do in interpreting verses in order to adapt to the guidance of the time. Therefore, all the thoughts contained in the Qur'an are immediately felt in need of reinterpretation. Baljon further added that this demand is felt necessary as a result of the touch with foreign civilization increasingly more intensive.

One of the mufastators of this era is Muhammad Abduh (1849-1905), he is a famous Islamic figure. Abduh began to write Qur'anic commentary on the advice of his disciple, Rasheed Ridha. Although at first he felt objection, he finally agreed as well. Abduh's description of the Qur'an gained the attention of one of the Orientalists, J. Jomier. According to him the analysis of Abduh is quite profound and a different thing from the Abduh review is his real desire to give the moral teachings of a verse.

In addition to Abduh, other Arab modernists were also many who had the same commentary as moderated, or equally conservatives. Until then came the method and a new way in the interpretation of the Qur'an. It is Thanthâwi Jauhari (d. 1940) who do not comment too much, but its reviews in the interpretation of the Qur'an can be a holding of biology or other sciences for 
society. Thus the book of Tafsirnya, Al-Jawâhir fi al-Tafseer Digadang-gadang as interpretation of the pattern.

Ahmad Mustafa ibn Muhammad ibn Abdul Mun'în al-Marâghi also listed his name as a row of modern exegetes with his tafseer, Tafsîr al-Qur'ân al-Karîm, often known as Tafsîr al-Marâghi. He was born 1883 and died in 1952. He wrote his tafseer for ten years, from 1940-1950. In his commentary, he posited the reason for writing the interpretation. He felt responsible for giving solution to the problem of concern that occurred in the community by sticking to the Qur'an.

In addition, Sayheed Quthb also appears with the Tafseer Fi Zhilali al-Qur'an and Aisha Abdurrahman Bintu Syathi ' with Tafsir al-Bayani Li al-Qur'anic alKarim.

In Indonesia also appeared several exegetes and the book of Tafseer. Among others: Tafsîr al-Qur'ân al-Karîm by Mahmud Yunus (1899) and Kasim Bakri, Tafsîr al-Furqân by Ahmad Hasan (d. 1887-1958), Tafsîr al-Qur'ân by Zainuddin Hamidi and Fakhruddin HS, Tafsîr al-Nûr al-Majîd by Hasbi alSiddiqi (1904-1975), Tafsîr Al-Azhâr by Buya Hamka (1908-1981) [30] and Tafseer al-Mishbah by M. Quraish Shihab.

The previous point of modern interpretation is that the 19th-century interpretation features a reformers-rational, science (Tafseer Ilmi) and literary style. Further developments, new studies have emerged in the science of interpretation, hermeneutics and semantic. Thus, it does not close the possibilities in the coming era there will be more methods of interpretation to reveal the meanings of the Qur'an.

\section{Patterns and Interpretation methods}

1. Tafseer Bi al-Ma'tsur

The means of the denial taken by the companions and the next generation are in the methodological framework, called the interpretation of Bil al-Ma'tsur (Periwayatan). The method of this investigation by Al-Zarqani is defined as all forms of information in the Qur'an, al-Sunnah or sayings of companions explaining the intent of Allah SWT on the Nash Qur'an. The method of BIL Ma'tsur has its privileges, but also has weaknesses. Its privileges, among others, are:

a. Emphasize the importance of discussion in understanding the Qur'an,

b. Display the accuracy of the editorial verse when delivering the messages,

c. Bind the exegetes in the text frame of the verses, so that the limiting it is subject to excessive subjectivity,

d. Can be used as the historical and information of the alliance that is beneficial for the next generation. 
On the other hand, the weaknesses seen in the books of commentaries relying on this method, as noted by some commentators, include:

1) The exegetes was affected in the blurring of the wordy linguistic and literature, so that the principal message of the Qur'an became blurred in the passage of the description,

2) Often the context of the decline of paragraph (description of Asbab alNuzul or the chronological side of the verses of the law understood from the description of the Nasikh/Mansukh) can almost be said neglected at all, so that the verses like descending not in one time Or be in the midst of a society without culture.

3) The occurrence of counterfeiting in tafseer due to the fanaticism of sect, politics and efforts of Islamic enemies.

4) The inclusion of the element of Isra'iliyat into interpretation, namely the Jewish and Christian elements into the interpretation of the Qur'an,

The development of the interpretation of the bi Al ma ' Tsur period is quite understandable because the mufastators rely on the mastery of language, as well as describe the accuracy in good, also they want to prove the cause of the Qur'an and its language. However, applying this method as well as proving the cause of it for the present, it is very difficult because we have lost the ability and taste of the Arabic language. The method of the investigation that they apply is also reasonably reasoned and has its privileges and weaknesses. This method is special when it is reviewed from a wide angle of historical information, as well as their objectivity in describing the history, to the extent that they convey the histories without the strict selcation. Imam Ahmad assesses that the interpretation is based on history, as do the histories of wars and heroism, all of which have no solid foundation.

Self-reasoned attitude of the last generation when relying on Qur'anic history. Because, then, the time between their generations with the generations of friends and Taabi'een is still close enough and the pace of social change and the development of science has not been so rapid. In addition, homage to friends, in their position as disciples of the Prophet and the people of Merit, and likewise against Taabi'een as the rank of second generation of Qurun, still very impressed in their souls. In other words, recognition of previous generations ' privileges over the next generation is still quite steady.

2. Tafseer Bi al-Ra'yi

Tafseer Bi al-Ra'yi is a type of interpretation method of Qur'an where a exegetes used the sense (ratio) as its main approach. In line with the above definition, Ash-Shabuni stated that the Tafseer of Bi al-Ra'yi was the interpretation of ijtihad built on the right foundations and found to be followed, not on the basis of ra'yu alone or on the encouragement of lust or 
interpretation of one's thinking At his own pace. While according to Manna alQattan, the Tafseer of Bi al-Ra'yi was a method of interpretation by making sense and his own understanding as a backrest in explaining something. [35] While AZ-Zarqani explicitly stated that the interpretation of Bi al-Ra'yi is an interpretation of ijtihad that is agreed or has a a isnaad to the proper and far from error and ignorance.

3. Tafseer Tahlily

Tahliliy interpretation method, or which Baqir Shadr named the Tajzi'iy method, is a method that seeks to explain the content of the verses of the Qur'an from various segments with regard to the prosecution of verses of the Qur'an as stated in the (Shadr, 1980:10). The way this method works consists of four steps, namely

a. Mufassir follows the sequence of verses as already composed in the Mushaf,

b. Described by expressing the meaning of the vocabulary and followed by explanation of the global meaning of paragraph,

c. To produce reasonable (coralation) verses and explain the meaning of the verses in each other,

d. Mufassir discussed the Asbab al-Nuzul and the evidence derived from the Apostle, companions and Tabi'in.

Weakness of Tahliliy method according to Quraish Shihab that interpreters are not uncommon only trying to find the evidence or more precisely the evidence of justification of Pendapat-pendapatnya with verses of the Qur'an. In addition, it feels once that this method is not able to provide answers to complete answers to the problems faced as well as not much given the methodological fence that can reduce its mufasctivity. Another drawback that is felt in the commentaries using the Tahliliy method that needs to be described is that the bahasan-bahasannya is perceived as binding to the following generations. This may be because the nature of the interpretation is very theoretical, not entirely referring to the interpretation of the specific problems they experience in their society, so that theoretical and general descriptions are impressive that it is Qur'anic view for every time and place. An example of this interpretation is the works of classical exegetes such as Tafseer "Jami ' al Bayan fa tafsir al-Qur'an ", by Ibn Jarir al-Tabari, the interpretation of Mafatih al Ghaib, by Fakhruddin al-Razi and others. Tafseer al-Tabari, seen from his corms including Tafseer Bi al-ma ' Tsur, which uses Tahliliy method, as well as the interpretation of al-Razi.

4. Tafseer Muqaran

In the systematic language, Said Agil Munawar and Quraish Shihab define the interpretation of the interpretation as a method of interpreting comparing the Qur'anic verses of the one with the other verses of the Qur'an that are equally 
redaction, but different problems or Comparing Qur'anic verses to the hadith of the Prophet Muhammad saw, which seems to contradict the verses, or compare the opinion of the other scholars of the interpretation of the same paragraph from some of the above, can Drawn some elements in Muqaran interpretation method:

a. Direction of exegetes tendency and factors that are behind him,

b. Interpretation of Quranic verses with other Qur'anic verses that are equally redaction but different problems,

c. Interpretation of the Qur'anic verses with the hadith of the prophet whose contents contradicts,

d. Opinion of the cleric with other opinion of Tafseer.

The papers included in the interpretation classification are contemporary writings, such as the Qur'an, Bible and Modern Science by Maurice Bucaile and Muhammad fi al-Torah wa al al-Qur'an, by Ibrahim Khalili (Rumi, 1413:57).

5. Tafsir Ijmaly

Tafsir Ijmaliy is a method of interpretation of the Qur'an that interprets the verses of the Qur'an by submitting the global meaning. In the systematics of his description, the exegetes discussed verse by verse according to his order in the Mushaf, then convey the global meaning of the verse in question. Thus the way this method is not much different from tahliliy methods, because they are bound by the sequence of verses as arranged in the Mushaf, and do not associate the discussion with other verses in the same topic except In general. The example of the interpretation using this method is the interpretation of Jalalain.

6. Tafseer Maudhu'i (Thematic)

Ali Khalil as quoted by Abd al-Hay al-Farmawi gives the boundary of thematic interpretation, which is: collecting Qur'anic verses that have a purpose and are allied with certain themes. Then, the verses may be arranged according to the chronology of descent accompanied by the understanding of the Asbab alNuzulnya. Then by the Exegetes commented, studied specifically in the thematic framework, reviewed all aspects of it, weighed with the right science, which in turn exegetes can explain according to the nature of the topic, so that the purpose can be found Easily and master it perfectly. so through this method, the interpretation is done by choosing the specific topic that the Qur'anic explanation should be, and then gathered all Qur'anic verses related to this topic, then look for the link between These verses in order for each other to be explained, just finally drawn the final conclusion based on the understanding of the intertwined verses.

If the notion of thematic interpretation we look at, then we can find the characteristics of thematic interpretation form, among others: 
a. The object of discussion or interpretation is not verse by verse as arranged in the order of the Ottoman Mushaf as applicable in the interpretation of Tahlilliy, but a specific theme that would like to know its meaning or understanding integrally according to The Qur'anic view,

b. The way it takes to gather all of the verses that are viewed intertwined and allied in one particular theme,

c. In the process of interpretation always pay attention to the chronology aspects of the decline of verses and Asbab al-Nuzul,

d. Before the verses are interpreted thematically, each verse and pronunciation contained therein are understood and reviewed and its various aspects, such as language, historical context, "Munasabat", etc.,

e. The interpretation of the Qur'an on a thematic basis also requires a variety of sciences, both of which belong to the "Ulum Al tafsir " and other relevant sciences, such as history, sociology, anthropology and so on,

f. The direction of thematic interpretation is always focused on a topic set,

g. The main purpose of which is to be achieved by thematic Tafseer as stated by Al-Farmawy in his book Al-Bidayah fi al-Tafsir al-Maudlu'i is to understand the meaning and Hidayah of the Qur'an and not merely know I'jaz Al-Qur'an, such as beauty The language or height of its literary values or the greatness of the other Qur'an.

One of the interpretations that popularized this method in Indonesia is M. Quraish Shihab with various works.

\section{CONCLUSION}

The Qur'an is an enduring source of Islamic law. The Qur'an is an infinity-edge ocean that keeps millions of divine pearls. To achieve it, everyone must swim and dive into the ocean of the Qur'an. Not all divers do what it wants because of its limited ability. This is where the urgency of the device science interpretation.

The science of interpretation has always evolved over time, even scholars have spawn many interpretations according to the demands of the times to assert the existence of al-Qur'an Salih Li Kulli Zaman wa eat.

There are many methods used in the interpretation of the methods of Tahlily, Ijmaly, Muqaran, and Maudhu'i.

\section{REFERENCES}

al-Banna, Gamal, , 2005, . Evolusi Tafsir: Dari Zaman Klasik Hingga Zaman Modern, Pent. Novriantoni Kahar, Jakarta: Qisthi Press, 2004.

al-Dzahabî, Muhammad Husain, , 2005, al-Tafsîr wa al-Mufassirûn, Kairo: Dâr alKutub al-Hadîtsah.

al-Marâghi, Ahmad Mustafa, Tafsîr al-Marâghi, vol. 1, h. 3. 
al-Qaththan, 1973. Manna al-Khallil, Mabâhis fî Ulûm al-Qur'ân, Riyadh: Mansyurat al-'ashr al-hadits

al-Siddiqi , Hasbi, 1900. Sejarah dan Pengantar Ilmu al-Qur'an-Tafsir, Jakarta: PT Bulan Bintang

al-Suyuthi, Jalaluddin, Al-Itqon fi 'ulum al-Qur'an, Cairo: Mathba'ah Hijazy, tt.

al-Zarqanî, Abdul Azhîm, , 1995. Manâhil al-Irfân fi Ulûm al-Qur'ân, Beirut: Dâr alMaktabah al-Arabiyah

Ghafur, Saiful Amin, , 2008. Profil Mufassir al-Qur'an, Yogyakarta: Pustaka Insan Madani

Ibn Taimiyyah, , 1971.. Muqaddimah fi Ushûl al-Tafsîr, Kuwait: Dâr al-Qur'ân alKarîm

J.M.S. Baljon, , 1991. Tafsir Qur'an Muslim Modern, pent A. Ni'amullah Mu'iz, Jakarta: Pustaka Firdaus

Mustaqim, Abdul, 2011. Epistemologi Tafsir Kontemporer, Yogyakarta: LKiS.

Shihab , M. Quraish, Membumikan al-Qur'an Bandung: Mizan, 1995.

Tim penyusun, Ensiklopedia Tematis Dunia Islam: Pemikiran dan Peradaban, Jakarta: PT Ichtiar Baru Van Hoeve. 